\title{
DESFIANDO O NOVELO FICCIONAL - LÚCIA MIGUEL PEREIRA E A REPRESENTAÇÃO DO CENÁRIO POLÍTICO
}

\author{
Edwirgens Aparecida Ribeiro Lopes de Almeida*
}

Resumo: Reconhecida por seu trabalho como crítica literária, Lúcia Miguel Pereira é pouco conhecida como romancista. $\mathrm{O}$ presente estudo tem o propósito de 'apresentar', de modo sucinto, as três narrativas de ficção Maria Luísa, Em Surdina e Amanbecer publicadas na década de 30 tendo em vista a vinculação da ficção aos acontecimentos daqueles tempos e, sobretudo, ao espírito ideológico predominante naquele contexto. Se a crítica literária contemporânea dos anos 30 reconheceu, na literatura nacional desse período, duas vertentes de escrita, a literatura social ou proletária e a literatura intimista ou psicológica, este estudo pretende ainda discutir a observação de Jorge Amado que acusa a autora de produzir romance engajado, subordinando conscientemente a criação a uma doutrina. Frente a esse apontamento do escritor baiano, notamos que, mais relevante que a vinculação da autora ao pensamento de direita ou de esquerda é o trabalho de representação de aspectos muito sutis da condição política e social daqueles tempos que foram 'recriados' pela autora, e transformados em elementos internos conduzindo a trajetória das personagens, principalmente femininas, e configurando, dessa forma, a razão de ser, sobretudo da obra Em Surdina. Se, para Jorge Amado, esses aspectos impediram o desenvolvimento da narrativa, a nosso ver, eles revelaram inquietações, anseios e temores femininos que integraram tanto a ficção quanto a crítica de Lúcia Miguel Pereira,

* Universidade Estadual de Montes Claros. 
dando forma assim a uma escrita intimista bastante coerente com o discurso predominante. Sendo assim, por vezes, a leitura dos relatos de ficção conduzem a uma revisão da subjetividade da autora associando-a àquelas subjetividades construídas em suas 'criaturas de papel'.

Palavras-chave: Ficção; história; crítica; década de 30; mulher.

Abstract: Recognized for her work as a literary reviewer, Lucia Miguel Pereira is little known as a novelist. The present study aims to 'present', succinctly, the three fiction narratives Maria Luísa, Em Surdina e Amanbecer, published in the 30s, in order to link the fiction to the events of those times, especially, to the ideological spirit prevailing in that context. If the contemporary literary criticism of the 30 s recognized, in the national literature of that period, two lines of writing, that is, the social or proletarian literature and the intimate or psychological literature, this study also intends to discuss Jorge Amado's observation which accuses the author of producing novels inspired by personal interests, thus consciously subordinating the creation to a doctrine. Considering that remark by the writer from Bahia, we note that more relevant than the author's bond to conservative or liberal thought is her effort of depicting very subtle aspects of political and social condition of those times which have been 'recreated' by her and changed into internal elements, leading the characters' path, especially the female characters, and, therefore, setting the reason for being, mainly in the work Em Surdina. If, for Jorge Amado, those aspects have hindered the narrative's development, in our view, they have revealed concerns, anxieties and women's fears, which had made part of Lucia Miguel Pereira's work, both in the fiction and in textual criticism, thus shaping an intimate written style quite consistent with the prevailing discourse. So, at times, the reading of the fiction narratives lead to a revision of the author's subjectivity, by associating it to those subjectivities which have been framed in her "paper creatures".

Keywords: Fiction; history; criticism; decade of 30; woman. 
Somente quando o apreciador se entrega com certa inocência a todas as virtualidades da grande obra de arte, esta por sua vez lhe entregará toda a riqueza encerrada no seu contexto.

Anatol Rosenfeld

Com uma intensa atividade no campo das letras, Lúcia Miguel Pereira figura como referência por seu trabalho de crítica e historiadora da literatura, porém sua produção como ficcionista ficou "deslocada para um discretíssimo pano de fundo", afirma Patrícia da Silva Cardoso (CARDOSO, 2006, p. 500). Lúcia Miguel, além de romancista e jornalista consagrada, foi pioneira na crítica literária, um reduto até então exclusivamente masculino. Destacando-se pela presença crítica e pelo senso de observação da realidade, o legado ficcional dessa autora não teve grande receptividade na época de sua escritura e, ainda atualmente, continua relegada, certamente, por uma tradição crítica que, sob o argumento de ser uma produção inferior em relação ao perfil de obras modelares, continua reproduzindo um estigma de texto em cada época.

Tal paradigma também norteou a escrita dos anos $30 \mathrm{em}$ escrita proletária/social e literatura intimista. A primeira, consagrada por escritores regionalistas como Jorge Amado e Rachel de Queiroz deixou, em segundo plano, a literatura voltada para o psicológico e a 'tensão interiorizada', como observa Alfredo Bosi (1985). Nessa última vertente, encontramos escritores como os mineiros Lúcio Cardoso e Lúcia Miguel Pereira que foram, durante algumas décadas, criticados pela falta de ação de seus escritos, o que para Luciana Stegagno Picchio, citada por Luís Bueno (2001), dá forma a uma "segunda via" do romance brasileiro.

Dando vida ao pressuposto de que a ficção se alimenta da realidade, Lúcia Miguel Pereira publica suas quatro narrativas intituladas Maria Luísa (1933), Em Surdina (1933), Amanbecer (1938) e Cabra-Cega (1954) numa autoria comprometida com a verdade sobre a vida humana, com as inquietações que figuravam 
a imaginação feminina e, sobretudo, sobre a degradação de valores em meio ao processo de modernização caótica do país. Ela mesma constata "'[c]onhece-te a ti mesmo'. Porque a verdade é que, malgrado todo o sociologismo objetivo que se vem insinuando no romance, tudo gira, em arte, em torno do eu e das suas relações com o mundo exterior" (PEREIRA, 1992, p. xiv). Transformando vivências, sonhos e experiências em matéria poética, as narrativas de Lúcia conduzem a mulher-leitora, contemporânea da década de trinta e dos anos cinquenta, para rumos e reflexões, às vezes, desconhecidos.

Ao lado da romancista Rachel de Queiroz e da poetisa Adalgisa Nery, Lúcia Miguel Pereira torna possível o conhecimento da intimidade psicológica e social das mulheres em tempos em que era evidente o controle das escolhas, das ideologias e das práticas femininas pelo provedor- o pai ou o marido. Como tais escritoras suas contemporâneas, Lúcia Miguel Pereira apropria-se da observação e da imaginação para dar vida às vozes femininas que emergem de seus textos. Mesmo que a autora se distancie das características mais evidentes do romance de trinta, como a denúncia social e o regionalismo, ela carrega a ficção de intensas problemáticas, sobretudo de tensões psicológicas vividas pela mulher desse tempo. Na base dessa questão, o crítico Antonio Candido relata que Lúcia "se preocupava muito com os problemas do espírito e da conduta em relação ao seu tempo" (CANDIDO, 2004, p. 127).

A par desse intuito, a ficcionista, polindo a verdade no estilo, conduz o leitor, a seu modo, à interpretação do momento seu contemporâneo. Propositadamente, as verdades da ficção admitem uma relação de conivência entre o autor e o leitor. Para isso, "o leitor, parceiro da empresa lúdica, entra no jogo e participa da 'não-seriedade' dos quase-juízos e do 'fazer de conta'", acrescenta Rosenfeld (ROSENFELD, 2005, p. 21). É essa relação de paridade estabelecida entre o criador e o receptor do discurso ficcional que desencadeia a mímesis a fim de promover o engajamento, a historicidade do trabalho artístico. Contradizendo 
a 'falta' de engajamento do chamado romance introspectivo ou intimista, é através de alguns pormenores que a autora visa a dar aparência de real à situação imaginária. Ao trabalhar as circunstâncias externas e internas que conduzem o texto, podese dizer com Anatol Rosenfeld que "é paradoxalmente esta intensa 'aparência' de realidade que revela a intenção ficcional ou mimética" (ROSENFELD, 2005, p. 20).

No intento de construção dessa verossimilhança, as narrativas de Lúcia Miguel Pereira são inclinadas a revisitar as ideologias, o espírito centralizador e autoritário da época. Sendo uma representante de uma elite intelectual, urbana e conservadora, Lúcia empresta muitas de suas convicções para suas personagens. É ela mesma quem escreve, em 1934, para o Boletim de Ariel, "aquele que se vê compelido a escrever não sendo essencialmente um poeta, encontra no romance um meio de expressão mais completo, mais natural" (PEREIRA, 1992, p. 30). Pode-se notar que Lúcia, além de se valer da crítica literária, faz do romance uma forma de expressão, e imprime nele as experiências de uma época. Destacando o viés documental dessa escrita intimista, salienta Luís Bueno que, "em certo sentido, portanto, a literatura de Lúcia Miguel Pereira na primeira metade da década pode ser vista como testemunho, apesar de a autora fugir completamente ao estereótipo do escritor social ao qual o testemunho estava ligado" (BUENO, 2006, p. 327).

Ainda no mesmo artigo apontado parágrafos atrás, Lúcia explica que o romance, através das situações e criaturas imaginárias, é capaz de satisfazer a curiosidade humana:

Essa curiosidade do documento humano, fruto da inquietação social crescente, ele [o romance] a satisfaz. Um romance, ainda quando muito fraco, é uma pesquisa, uma experiência para ver se a vida é possível em determinadas circunstâncias. A necessidade cada vez maior de simpatia, de contato com os nossos companheiros de jornada, nos leva a buscá-los mesmo entre as criaturas imaginárias (PEREIRA, 1992, p. 30). 
No trecho supracitado, a autora admite o papel social da literatura além de ratificar o estreito limiar entre os fatos e a ficção. E esclarece a facilidade desse tipo de composição quando destaca "também não é impossível, a qualquer um, imaginar e contar histórias mais ou menos verossímeis" (PEREIRA, 1992, p. 29).

Assim, pelas páginas das narrativas Maria Luísa, Em Surdina e Amanbecer, a ficcionista possibilita uma sutil alusão ao governo getulista dos anos 30. Nesta época, o governo de Getúlio Vargas, forte, centralizador e autoritário, tem como guia a figura do presidente. O historiador Bóris Fausto explica que, no curso do Estado Novo, "construiu-se a figura simbólica de Getúlio Vargas como dirigente e guia dos brasileiros, em especial dos trabalhadores, como amigo e pai, semelhante na esfera social ao chefe de família. O guia e pai doava benefícios a sua gente e dela tinha o direito de esperar fidelidade e apoio" (FAUSTO, 2008, p. 207).

Como a arte permite uma visão fragmentada da realidade, o foco dessa centralização ganha corpo na ficção quando a sociedade é, nestes termos, simbolizada pela família. Na ficção, Lúcia cria um microcosmo doméstico, num ambiente semelhante ao que se passava na política e na vida social da nação. É o pai, o chefe e o detentor do controle da família a quem todos devem reverenciar. Exceto em Maria Luísa, onde esse papel fica, em grande medida, a cargo da protagonista homônima. No plano estético, é interessante observar que quem faz esse papel é o narrador. $O$ olhar do narrador sobre a família se assemelha ao olhar controlador do estado sobre a sociedade, porém, na ficção, o narrador faz, através da ironia, uma certa desconstrução daquela condição social e política. Mesmo distante, o narrador consegue visualizar as ações e os pensamentos familiares como se estivesse de perto, ao modo das atitudes do corpo político que se traduzia como ações do presidente. De forma alegórica, a autora põe em evidência as tradições a partir da dinâmica familiar, sobretudo das posturas femininas, assim como o governo procura pôr em destaque o controle da sociedade em favor da nação. Nesse 
sentido, a família representa, alegoricamente, uma limitada visão da máquina administrativa.

Como proposta do governo getulista, a educação preocupou-se com a formação de uma elite intelectual e acabou ganhando inspiração autoritária. Cândido Moreira Rodrigues estuda os princípios desse Governo projetados na Revista $A$ Ordem, para a qual também contribuiu como escritora Lúcia Miguel Pereira, e destaca entre falas do próprio presidente Getúlio, que os órgãos do governo tinham a "incumbência de difundir os 'princípios uniformes de disciplina cívica e moral' nos meios educacionais, objetivando imprimir-lhes rumos de 'nacionalismo sadio', de forma que, nesta matéria, tudo deveria emanar do poder federal"1 (RODRIGUES, 2005, p. 124).

Representado entre críticas e ironias, entendemos que há ressonâncias do lema "Deus, Pátria e Família" enredando o tecido ficcional nas tramas, já que objetivava a tomada de consciência do valor espiritual da nação. Uma importante base de apoio do governo de Getúlio Vargas foi a Igreja Católica. Tais princípios figuram como cimento na construção dos romances de Lúcia, embora a autora vá, antagonicamente, revelando a hipocrisia em que os dogmas religiosos estão calcados, porém ratifica a importância deles na concepção da família. Embora o livro Maria Luísa não faça referência a um determinado tempo histórico, é condizente com o espírito da época em que foi publicado. Nessa obra, o narrador, com um olhar irônico sobre o ensino religioso, comenta sobre as crenças de Maria Luísa: "Dessas aulas, o que de mais claro lhes ficou, foi uma ideia de ordem social intransponível e rígida, mantida, aliás, por um Deus muito cheio de etiquetas e convenções que lhes descreviam a mãe e a tia" (PEREIRA, 2006, p. 26). Para esclarecer as ideologias reinantes

\footnotetext{
${ }^{1}$ Os trechos em destaque nos comentários de Cândido Moreira Rodrigues são falas do presidente Getúlio extraídas por Rodrigues de VARGAS, Getúlio. Problemas e realizações do Estado Novo. In: A nova política do Brasil. Tomo V. Rio de Janeiro: José Olympio, 1938. p. 182-183.
} 
naqueles tempos e estabelecer o diálogo da arte com a história, importa ressaltar o lugar ocupado pela vontade da Nação organizada no discurso do presidente Vargas, destacado por Cândido M. Rodrigues.

As lições do passado evidenciam... que o Brasil é um país de ordem. Ordem e democracia que significam disciplina e liberdade, obediência consciente e acatamento ao direito. Repelimos os surtos demagógicos, como não toleraríamos a tirania. [...] Os agentes de subversão e da desordem persistem nos seus planos diabólicos. [...] É da tática comunista a dissimulação e o embuste. [...] Para continuarmos a desfrutar a paz e a tranquilidade... torna-se imprescindível manter constante vigilância (RODRIGUES, 2005, p. 129).

As diretrizes marcadas no discurso político de direita vão sendo pari passu delineadas e criticadas nas páginas literárias de Lúcia Miguel Pereira. A preocupação com a ordem, com a estrutura social que disciplina a sociedade no governo getulista marca a existência das personagens. A ausência de fervor da protagonista nas práticas religiosas é, para o narrador, uma aproximação da postura do pai, "livre pensador e ateu" (PEREIRA, 2006, p. 26). Mesmo não crendo nos dogmas católicos, Maria Luísa mantém suas atividades piedosas e passa a viver uma vida aparente a fim de não romper os protocolos e a educação religiosa católica dos filhos, que acredita ser necessários.

Já Lúcia Miguel Pereira, embora atue como defensora da ideologia católica tanto nos escritos para a revista $A$ Ordem quanto nos textos de ficção, revela não se ligar a nenhuma religião. Carlos Drummond de Andrade, em trecho de seu diário de 1959, citado por Bernardo de Mendonça esclarece: "Octavio (Tarquínio de Sousa) disse que sua mulher, Lúcia Miguel Pereira, também não pratica qualquer credo religioso...” (MENDONÇA, 1992, p. xix). Diante dessas constatações, Luís Bueno questiona se a inserção de Deus no último capítulo de Em Surdina é uma estratégia da 
autora para impedir que o leitor conclua a possibilidade da mulher encontrar a felicidade fora dos padrões preestabelecidos pela religião. Destaca, ainda, que esse realce para a entrada de Deus na história está ali para "marcar claramente uma posição que é da autora e não da personagem" (BUENO, 2006, p. 201).

Dialogando com o contexto histórico, convém reiterar que o poder centralizado do governo de Getúlio assemelha-se ao poder do pai numa ambiência patriarcal ou ao papel do narrador, nos romances em questão. Assim como faz o governo, o narrador observa a organização da família mesmo vendo nela os alicerces frágeis e hipócritas. Por outro lado, a atuação do narrador pode ser entrevista como uma crítica aos parâmetros em que a família e a sociedade, de modo geral, estavam assentadas. No plano social, destaca-se que, com a Revolução de 1930, os trabalhadores gradativamente foram controlados pelo Estado que, em troca das leis trabalhistas, procurava impedir greves e sindicatos. Em 1934, tal situação foi legitimada pela Constituição. Com esse caráter paternalista e cooperativista, com "traços fascistas", o controle do trabalhador foi gradativamente associando-se ao discurso da família. Nesse viés, o Estado enquanto pai, assim como os burgueses nas indústrias, procurava controlar os filhos e punir os 'rebeldes' que geralmente eram associados a anarquistas ou comunistas. Esta perspectiva corroborava o discurso de cunho fascista da Ação Integralista Brasileira (AIB) de "Deus, pátria e família". Na instância ficcional, comenta o narrador do romance Maria Luísa: "a palavra pátria não correspondia para ela a nada de preciso. Não alargava até lá a consciência familiar. Nunca pensara que o futuro dos filhos e o futuro do Brasil eram, em alguns pontos, estreitamente ligados" (PEREIRA, 2006, p. 116).

O clima ideológico dos anos 30 foi percebido tanto na literatura social e proletária quanto na intimista. Falando sobre essa presença nos textos ficcionais, Jorge Amado, escrevendo sobre $E m$ Surdina, em 1934, para o Boletim de Ariel, acusa a autora de 'produzir romance engajado, subordinando conscientemente a 
criação a uma doutrina'. Luís Bueno destaca os trechos em que Amado aponta a escrita de uma intelectual 'da direita': "Sinto também que a romancista vive presa a um círculo de ideias das quais não se pode libertar, o que the restringe as possibilidades, impedindo o desenvolvimento completo do romance, o aproveitamento de certos detalhes. Compromissos talvez, que roubam parte da independência da escritora" (BUENO, 2006, p. 201). Ora, a observação de Jorge Amado de que a tendência ao pensamento predominante da época condicionou o desenvolvimento da ficção de Lúcia Miguel sugere que a literatura daquele momento representa bem aquele teatro social, mediada pelos pensamentos de direita ou de esquerda, o que põe em relevo certos antagonismos na ficção. Sobre o objeto de ocupação desses movimentos, vale acrescentar o comentário do historiador Boris Fausto.

Os integralistas baseavam seu movimento em temas conservadores, como a família, a tradição do país, a Igreja católica. Os comunistas apelavam para concepções e programas que eram revolucionários em sua origem: a luta de classes, a crítica às religiões e aos preconceitos, a emancipação nacional obtida através da luta contra o imperialismo e da reforma agrária (FAUSTO, 2008, p. 195).

Tendo em vista a contradição existente nos textos de Lúcia Miguel Pereira, pode-se notar que as ideias destacadas pelo historiador estabelecem um embate constante nos romances que vimos examinando, seja através da crítica, da ironia ou da conformação.

Fazendo uma breve leitura da relação existente entre a obra Em Surdina e as primeiras décadas do século XX, vale lembrar que o enredo desse livro se passa do ano de 1917 aos anos 20 adentro, tratando do momento de transição representado pela Primeira Guerra Mundial e de seus desdobramentos. Seguindo o casamento de Antônio, gêmeo de João, com uma moça de família tradicional, inicia-se a revolta dos dezoito do forte de Copacabana. Antônio, então, mostra que se posicionará, com o apoio da família, favorável 
ao lado da direita na polarização que se estabelecerá com o governo de Getúlio. "O mundo precisa antes de nada, de ordem e de disciplina. O princípio da autoridade deve ser mantido à custa de qualquer sacrifício. Admirar os revolucionários só porque morreram é um sentimentalismo ridículo" (PEREIRA, 1933, p. 294).

Essa posição da personagem conforma com as convicções ideológicas do pensamento de direita, aspecto que, segundo Jorge Amado, tolhe a imaginação da artista na feitura de seus romances. Por esse lado, o legado romanesco abraça a questão já que, no âmbito internacional, convém destacar que, após a crise de 1929, a emergência do "estado de bem-estar social" e mesmo os regimes totalitários associavam o bom comportamento do indivíduo ao Estado, o que fazia com que o discurso deste último estivesse, constantemente, vinculado ao discurso da família. Em regimes de direita (nazifascistas) e na política varguista até o ano de 1945, os comunistas eram considerados como aqueles que agrediam a "ordem" familiar e estatal. Alceu Amoroso Lima acredita que a Igreja Católica deveria, por princípio, repudiar o comunismo. Rodrigues destaca o trecho em que Amoroso Lima escreve para A Ordem, sugerindo que:

Precisamos enfrentar o Comunismo como uma negação integral do Cristo e da Igreja e não como um fenômeno social passageiro, que afeta apenas os nossos interesses materiais ou nossas posições sociais. Seu perigo é infinitamente mais profundo...; reveste-se... da aparência de justiça, do êxito e do progresso. Só se nos colocarmos no terreno dos princípios é que poderemos enfrentar friamente essa ideologia revolucionária (RODRIGUES, 2005, p. 173).

No romance Amanbecer, narrado em primeira pessoa pela protagonista Maria Aparecida, aflora essa crítica às ideias comunistas. A chegada de Antônio se configura no motivo desencadeador das transformações na vida da protagonista. Conhecido por suas ideias complexas e inconvenientes, Antônio 
é visto, a princípio, como maluco, uma vez que dissemina a ideologia comunista. Inicialmente, a tradicional Maria Aparecida se horroriza com o discurso de Antônio até passar a ver nele um aprendizado: "Antônio também defendia o que ele chamava de maternidade consciente. Por isso não me espantei, nem me escandalizei (...) estava agora livre de tudo isso, que sabia, graças a Antônio, que a confissão era um meio que os padres tinham de dominar o povo" (PEREIRA, 1938, p. 117-141). Como a abertura da disputa política facilitou um afrouxamento das medidas repressivas, o narrador parece também conceder alguns avanços no comportamento dos personagens, o que revela uma crítica da narração frente a essa atuação religiosa e política. Isso se dá em Amanbecer que, publicado em 1938, permite maior liberdade de pensamento e ação que Maria Luísa e Em Surdina, ambos de 1933. Por outro lado, podemos entender a assimilação das ideias comunistas por Maria Aparecida, uma vez que ela é a única protagonista que não é burguesa. De certo modo, algumas aspirações da bandeira desses movimentos eram desfavoráveis às elites burguesas, o que nos faz pensar novamente no papel ocupado pela mulher e na classe social de cada protagonista. Contudo, como o desfecho da trama depende da imposição da autoria, esta não permite a plena realização da personagem após a absorção de alguns daqueles princípios. Essa vulnerabilidade às tendências ideológicas acontece de maneira bem expressiva se analisarmos os romances através das práticas dos tempos. Como o governo Vargas se estende de 1930 a 1945 , esses modernismos passam a ser mais facilmente assimilados pela sociedade, podendo ser vistos com outro olhar pelas próprias personagens e pelo narrador.

Como vimos destacando, são da natureza do narrador os julgamentos acerca dos comportamentos dos integrantes e suas posições dentro da manutenção da ordem familiar. Ambiguamente, nos textos em questão, as personagens parecem querer ganhar vida própria, ao contradizer os parâmetros preestabelecidos, mas deparam-se constantemente com a observação desse narrador ou 
de algum personagem que, ao invés de agir, reflete sobre os acontecimentos. Portando certo sentimento de verdade, a representação sutilmente comparada com a situação política dos anos trinta remete-nos às bases em que foi construída a administração getulista. Nesta, o olhar atento da máquina administrativa censurava a população de modo a fazê-la aceitar passivamente a sua condição. Um breve olhar sobre o Brasil dos anos 30 e 40 revela que a aproximação entre a Igreja e o Estado garante a este último auxílios de duas ordens. Rodrigues comenta que "primeiro, no campo político e, segundo, no campo da domesticação das consciências, tendo como ponto comum entre ambos o combate à luta de classes" (RODRIGUES, 2005, p. 139). Há aqui uma crítica às ideias e às práticas da Igreja Católica e à ocupação da mulher no lar e no espaço público.

Nesse controle exercido pelo narrador sobre os leitores, percebe-se a consciência da autora de que a ficção orienta o comportamento feminino. Haja vista uma herança de pai para filho, o acervo apresenta fortes indícios de que o ponto de vista da autora é transferido para as personagens, sobretudo para o narrador. Nesse sentido, Naomi Segal (1997) ressalta que o texto funciona como um enunciado sintomático do narrador, que, por sua vez, é motivado pela fantasia do autor. Essa estratégia da autora de atribuir poder de julgamento ao narrador a exime de qualquer culpa e punição pelos juízos levantados.

No contexto da época, as soluções autoritárias tornaramse uma prática constante. Investindo contra os princípios comunistas, explica Bóris Fausto que

[a] corrente autoritária assumiu, com toda a consequência, a perspectiva do que se denomina modernização conservadora; ou seja, o ponto de vista de que, em um país desarticulado como o Brasil, cabia ao Estado organizar a nação para promover dentro da ordem o desenvolvimento econômico e o bem-estar geral. Nesse percurso, o Estado autoritário poria fim aos conflitos sociais, às lutas 
partidárias, aos excessos da liberdade de expressão, que só serviam para enfraquecer o país (FAUSTO, 2008, p. 195-196).

Como as práticas ficcionais combinam com a história, as narrativas de Lúcia vindas a público na década de 30 coadunam-se com a preocupação sobre os excessos de liberdade propagados pelos meios de comunicação. Do lado da história, esses veículos de comunicação são valiosos instrumentos na construção da imagem de Getúlio como protetor dos trabalhadores. Através deles, Getúlio se dirigia a audiências determinadas: às mulheres, aos aposentados, migrantes, aos pais de menores operários, com o propósito do controle social. O ano de 1939 vem legalizar esse controle exercido anos antes através da criação do DIP (Departamento de Imprensa e Propaganda). Segundo Fausto, o DIP:

recebeu funções bastante extensas, incluindo o cinema, $o$ rádio, o teatro, a imprensa, a literatura "social e política", a organização do programa de rádio oficial do governo, a proibição da entrada no país de "publicações nocivas aos interesses brasileiros", a colaboração com a imprensa estrangeira a fim de se evitar que fossem divulgadas 'informações nocivas ao crédito e à cultura do país' (FAUSTO, 2008, p. 207-208).

Do lado da ficção, fomentada pelas contradições do tempo, Lúcia também pinta a apreensão pela entrada no país de "publicações nocivas aos interesses brasileiros". Nesses três romances, a literatura figura como o principal fator desencadeador das mudanças que a autora considera, em grande medida, nocivas à tradição e à ordem, sobretudo da vida das mulheres. Diante das desilusões de Maria Luísa, ela "já não tinha essa mania de ordem, garantia, em muitas mulheres, de uma vida moral bem equilibrada... Devorava romance sobre romance, com a sofreguidão de uma adolescente sentimental. Era o seu único refúgio, o mundo da imaginação. Mas que perigoso abrigo!..." (PEREIRA, 2006, p. 89-90 Grifo nosso). Podemos localizar aqui que o narrador dá realce ao perigo decorrente da leitura. Há, na 
citação, uma ironia à falta de leitura feminina naqueles tempos, pois o discurso patriarcal orientou que, se as mulheres enveredassem pelas histórias de romances, provocariam o desequilíbrio da ordem familiar, já que eles, os enredos, fertilizariam a imaginação feminina.

Assim como os instrumentos do Estado construíam as aparências da sociedade, o acervo ficcional dos anos trinta de Lúcia Miguel também propõe certa crítica àquela ordem aparente, o que, para algumas personagens significa abdicar, muitas vezes, de suas convicções ou dos prazeres individuais em favor do coletivo, como o faz Maria Luísa. Esta, que encontrou a paz na vida de aparências e de hipocrisias, tendo reconhecido seu erro ao efetivar a traição ao marido, sabe-se agora uma pessoa passível de erros. Apontando esse princípio católico, Cândido Moreira Rodrigues recorta trecho de Jacques Maritain, "considerado a figura mais alta do pensamento filosófico católico contemporâneo - segundo o qual'os católicos não são o catolicismo: os erros, as lentidões, as falhas e a passividade dos católicos não comprometem o catolicismo. [...] A grande glória da Igreja consiste em ser Santa com membros pecadores" (RODRIGUES, 2005, p. 174).

As personagens dos romances em questão também trazem consigo essas convicções que, por sua vez, devem ser de conhecimento da autora, uma vez que ela era conhecedora dos pensamentos de Maritain, deixando alguns textos críticos acerca deles. É relevante notar que, nessa data da criação dos órgãos de construções imagéticas do Estado (1939), Lúcia já havia publicado três de seus quatro romances. Porém, pelo exposto, vê-se que seus escritos evocavam todo o espírito de 'entrada do país nos tempos modernos', como a autora reiteradamente descreve nos artigos e na ficção, através das personagens, como 'tempos de modernismo' em contraposição à 'velha ordem'.

Marcados pela nostalgia de certos tempos, esses romances dão forma a uma crítica à situação política dos anos 30 , mormente da vida privada das mulheres engendrada pelo olhar do narrador. Tal discurso questiona a liberdade feminina, mas culmina por 
mostrar a dificuldade de integração social da mulher. Embora as mulheres pretendam alçar novos voos, esses seus instintos vão sendo minados pelas limitações impostas a elas naquele contexto. Dessa forma, procuram novas formas de vida, mas não se realizam completamente no final.

Com base nos esclarecimentos expostos, nossa leitura vem desmitificar a afirmação de que a literatura intimista não carrega a tônica desse tempo, já que não se caracteriza literariamente como escrita 'social e política'. Revisitando o legado de Lúcia Miguel, percebe-se que, com uma maneira diversa de recortar as relações sociais, cria um universo particular em torno da família e põe em destaque as problemáticas do tempo, sobretudo decorrentes do acesso da mulher ao espaço público, ao mercado de trabalho e ao prazer individual. Por conseguinte, vê-se que a ficção de Lúcia Miguel Pereira, embebida na ambiência histórica, não falseia, mas traz esteticamente transformados os anseios femininos diante do quadro político e ideológico existente nos anos trinta. E isso confere verdade a seu texto, aspecto que a aproxima à escritora inglesa Virgínia Woolf, quando esta salienta que "a ficção deve aterse aos fatos e, quanto mais verdadeiros os fatos, melhor a ficção" (WOOLF, 1985, p. 23).

É com base nessa premissa que nos ateremos a mostrar, sucintamente, o tênue limiar existente entre os fatos e a ficção, na obra Em Surdina. Adentrando a instância narrativa dessa obra, pode-se perceber que os elementos mais recorrentes a fim de compor a verossimilhança do texto são o espaço, o tempo, o clima ideológico e alguns fatos do período retratado. Para marcar a história na ficção, o espaço e o tempo são evocados através da imaginação ou de reminiscências das personagens. Desse modo, oscilam entre a temporalidade do contexto, o tempo e o espaço "imaginário" e "real" da ficção, pois como adverte Benedito Nunes, "o temporal e o espacial nas artes formam domínios mutuamente permeáveis, que não se excluem” (NUNES, 2000, p. 11). 
Em Em Surdina, espaço e tempo são marcados, sobretudo, pela imaginação da personagem Cecília. A história se inicia com uma viagem de ônibus da protagonista pelas ruas do Rio de Janeiro. Cecília observa as ruas por onde passa, e as pessoas enquanto reflete sobre o pedido de casamento do Sr. Jorge Reis. Do espaço e do tempo real da ficção dos quais fala a protagonista, o leitor é remetido aos acontecimentos de sua imaginação. A mesma imagina comentários futuros se aceitasse o pedido, “- Você sabe! A Cecília Vieira teve uma sorte louca! Casou-se com Jorge Reis, o filho de Felisberto, o do Banco Agrícola. Montaram uma casa linda em Laranjeiras. Laranjeiras ou Copacabana? Copacabana era mais alegre, mais moderno... Mas Laranjeiras era mais distinto" (PEREIRA, 1933, p. 07). Vejamos que é através da imaginação que a personagem nos remete ao espaço. Cabe também ressaltar que o destaque dado à distinção desses espaços situa o leitor na condição econômica de Cecília, bem como na preocupação com a manutenção das aparências. Tendo em vista as aspirações da protagonista é possível se pensar na condição que ela ocupa na sociedade. Sem perder de vista a estreita ligação entre invenção e registro da realidade, vale destacar que, ademais de outras similitudes entre a protagonista e a autora, é no bairro de Laranjeiras, no Rio de Janeiro, que também viveu a escritora Lúcia Miguel Pereira.

Com uma descrição longa e minuciosa da trajetória de Cecília até a costureira, ruas, casas, o colégio em que estudou, tudo o que olha conduz à recordação do passado e às aspirações do futuro. "Trechos de ruas e fisionomias desconhecidas misturavam-se às visões interiores" (PEREIRA, 1933, p. 09) em que a observação de uma senhora de vermelho "foi como a tela onde se projetaram as fantasias da imaginação" (PEREIRA, 1933, p. 09). Inquieta entre o comodismo do passado, a instabilidade do presente, representada pelo pedido do casamento, e a incerteza do futuro, a personagem central de Em Surdina, simboliza bem o momento de transição no qual se passa a história. 
Numa observação atenta, Luís Bueno destaca trecho do Boletim de Ariel publicado um mês antes do lançamento de Em Surdina em que Lúcia Miguel Pereira trata da diferença entre as duas gerações, de antes e depois da primeira guerra: "os moços aludem, zombeteiros, aos requintes e à artificialidade dos homens de antes da guerra, e estes atribuem à mentalidade apressada, pouco culta dos de após guerra, todos os desmandos do mundo atual" (BUENO, 2006, p. 316). É lícito apontar como a autora observa em sua crítica, a mudança de comportamentos provenientes da turbulência do tempo e tais constatações são naturalmente transpostas para a prosa de ficção. Marcada pelas contradições desse tempo, a narrativa investe nos grandes saltos temporais sem perder de vista alguns importantes acontecimentos que marcam o tempo e o espaço da obra, bem como o espírito ideológico de suas personagens.

Já no capítulo I, a investida dos alemães contra a França, referência feita ao ataque no campo de batalha de Verdun, nordeste da França, em 1916, servem de pano de fundo para as conversas durante o jantar na casa do Dr. Vieira, pai de Cecília.

- A situação é gravíssima, comentou Dr. Vieira; a nossa civilização está por um fio (...)

- Vai ser a mesma coisa que em 70, opinou Antônio... Vocês vão ver; os alemães vão acabar de uma vez com a prosa dos franceses.

- Meu filho, repreendeu o cirurgião, o momento não está para brincadeiras. Nós brasileiros não temos mais direito de ter opinião; devemos formar como um só homem ao lado dos aliados. Você sabe qual será o seu futuro, qual será o futuro das suas irmãs se tivermos a desgraça de ver vitorioso Guilherme II? (PEREIRA, 1933, p. 21).

Os diálogos travados entre as personagens permitem ver as posições ideológicas que vão se formando, além da posição conservadora que o pai, provedor da família, estabelece como condição para o futuro das filhas. Para ele, as mulheres são as principais prejudicadas por terem alteradas as condições tradicionais 
dessas na sociedade. Essa conversa se configura como uma crítica à condição social da mulher e também parece ser um pretexto para que a narrativa revele as distintas personalidades com as quais $o$ leitor se deparará, sobretudo para mostrar também o clima de tensão que mediará a escrita e irá interferir no desfecho da trama.

O Capítulo VIII ficcionaliza a pandemia de gripe, conhecida como gripe espanhola, ocorrida em quase toda parte do mundo em 1918. "Quase todos estavam doentes ou tinham estado" (PEREIRA, 1933, p. 161). A família do Dr. Vieira é atingida pelo vírus, levando à morte de Tia Marina, e deixando Cecília e o irmão João carentes de cuidados especiais, o que levou os dois a um período de quatro meses no interior do Rio. A decisão da retirada dos dois para o interior com o objetivo de curar a doença acontece no dia 11 de novembro de 1918, não coincidentemente é o 'Dia do Armistício', dia do fim simbólico da Primeira Guerra Mundial, em que o acordo é assinado entre os Aliados e o Império Alemão, em Compiègne, na França, pelo fim das hostilidades na Frente Ocidental. Apesar de essa data oficial ter marcado o fim da guerra, refletindo no cessar-fogo na Frente Ocidental, as hostilidades continuaram em outras regióes. Com os desdobramentos da guerra, Cecília e João encontram ali uma tranquilidade simbólica. Deixando de lado a doença, a protagonista ainda dá seguimento às inquietações decorrentes de sua indecisão sobre como viver, se casar ou não. Apesar de uma aparente melhora, João necessita ser enviado à Suíça para tratar a pneumonia, decorrente da virose.

Mais uma recorrência histórica que, a nosso ver, não funciona apenas como informações isoladas da estrutura narrativa, pois acreditamos que, trabalhando formalmente essas correspondências, a autora consegue dar o formato estético de sua obra. No caso da ocorrência ficcional da pandemia de gripe, esta figura aqui como um elemento determinante na vida de Cecília e de João. Para ela, é o contato com a simplicidade e o modo 'brusco' de lidar com as durezas da vida pelo homem do campo que faz Cecília repensar o seu estar no mundo e, consequentemente, o pedido de casamento feito por 
Paulo. Já para João, o agravamento de sua doença não se dá para que a narrativa mostre a intensidade do problema enfrentado pelo Brasil e outros países naqueles tempos. Essa retirada estratégica para a Suíça para efeito de tratamento ocorre para que lá a personagem possa contatar outras realidades e novas ideologias que serão geradoras de tensões nas quais a narrativa está assentada. Ao retornar da Europa, João, contaminado pelas ideias de liberdades individuais, decide ser escritor e jornalista, 'discutia a renovação artística e literária e política europeia'.

Logo de chegada, travara relações com um grupo de rapazes da novíssima geração, inimigos dos preconceitos e do intelectualismo. Levava a perambular com eles pelas ruas da cidade, debatendo credos artísticos e políticos. Mas não se filiava à corrente modernista. Ao contrário. -Ofuturismoé um movimento natimorto, uma macaqueação, sentenciava. Como tentativa de libertação falhou. É a arte do homem dominado pela máquina.

Ele se ligara intimamente, na Suíça, com um hindu, leitor de Romain Rolland e de Schuré, discípulo do filósofo Keyser-ling na sua escola de Darmstadt (PEREIRA, 1933, p. 292-293).

Pelo exposto, na atuação da personagem escritor $\mathrm{e}$ jornalista podemos perceber que, mesmo não se filiando às correntes modernistas, as desagregações estéticas decorrentes da Semana de Arte Moderna também figuram como preocupações e temas de discussão nos registros ficcionais.

Ambientando ficção e clima político, encontramos de 1922, a referência ao levante do forte de Copacabana. "Claudio vibrou com a epopeia dos 18. - Só lamento não ter morrido com eles, repetia" (PEREIRA, 1933, p. 294). Contraditoriamente ao espírito revolucionário de um, encontramos Antônio que 'era contrarevoluções, por índole e por convicção', posicionando-se, já nesse momento, ao lado dos princípios pregados pela direita, anos mais tarde. Como vimos notando, esse romance também critica o receio de algumas mudanças quando põe em questão o predomínio do 
discurso tradicional ao passo que, por outro ângulo, revela a crise e a hipocrisia do patriarcado. A personagem Antônio é um dos símbolos dessa crítica da tradição por agregar várias condutas que antipatizam o leitor.

Buscando no âmago do texto literário um encontro com a história, podemos identificar em toda a estrutura interna da narrativa uma ligação com o clima político, marcado pela transição entre a primeira e segunda guerra. A indecisão de Cecília acerca do experimento do casamento, o contraste entre o pai de família e o destino de seus filhos: "Nenhum tipo de continuidade haverá entre as duas gerações” (BUENO, 2006, p. 317), adverte Luís Bueno.

De maneira geral, a família termina numa situação menos privilegiada do que aquela do começo. O pai apresentava sinais de declínio, seja na profissão, seja na aparência. "Em todos os terrenos, o declínio começava, lento, mas fatal. Eram sinais imperceptíveis... mas quem o conhecia bem, via que já não era o mesmo homem, que já não tinha a mesma arrogante confiança em si" (PEREIRA, 1933, p. 304). Sob a ação do tempo, o pai representante do homem antes da guerra - entra em declínio, enquanto que seus filhos, representantes do pós-guerra, trazem posturas bastante vulneráveis. Cecília representa a indecisão, Cláudio se mata por endividar-se com o jogo, Heloísa mantém um casamento de aparências enquanto sustenta sua relação com os amantes, os filhos João e Antônio são portadores de ideologias opostas e partidárias.

Por conseguinte, em detrimento do exercício artístico da escritora, a artista em questão aproxima realidade e imaginação a fim de compor a sua poética individual. Partilhando ainda com Luiz Costa Lima a ideia de que "a fiç̧ão não representa a verdade, mas tem por ponto de partida o que produtores e receptores têm por verdade" (LIMA, 2000, p. 64), Lúcia Miguel Pereira delega ao leitor o papel de desenrolar os fios do novelo ficcional e extrair, pela interpretação, os nós que amarram as verdades na intuição. Nesse reduto, a autora, ciente das contradições por que passa a 
sociedade da época, mesclando invenção e observação, constrói uma narrativa sutil, deixando entrevistas no emaranhado do texto uma representação do cenário histórico.

\section{REFERÊNCIAS}

BOSI, A. História concisa da literatura brasileira. São Paulo: Cultrix, 1985.

BUENO, L. Guimarães, Clarice e antes. Tereza. Revista de Literatura Brasileira. Departamento de Ciências Clássicas e Vernáculas FFLCH/ USP, n. 2. São Paulo: Ed. 34, 2001.

BUENO, L. Uma bistória do romance de 30. São Paulo: Editora da Universidade de São Paulo; Campinas: Editora da Unicamp, 2006.

CANDIDO, A. O albatroz e o chinês. Rio de Janeiro: Ouro Sobre Azul, 2004. p. 127-132.

FAUSTO, B. História Concisa do Brasil. 2. ed. 1. reimpr. São Paulo: Edusp, Imprensa Oficial do Estado, 2008.

LIMA, L. C. Mímesis: desafio ao pensamento. Rio de Janeiro: Civilização brasileira, 2000.

MENDONÇA, B. de. A leitora e seus personagens: profecias e memórias dos anos 30. In: PEREIRA, L. M. A leitora e seus personagens: seleta de textos publicados em periódicos (1931- 1943), e em livros. Prefácio, Bernardo de Mendonça; pesquisa bibliográfica, seleção e notas, Luciana Viégas- Rio de Janeiro: Grafia Editorial, 1992. p. xii-xx.

NUNES, B. O tempo na narrativa. 2. ed. São Paulo: Ática, 2000.

PEREIRA, L. M. A leitora e seus personagens: seleta de textos publicados em periódicos (1931- 1943), e em livros. Prefácio, Bernardo de Mendonça; pesquisa bibliográfica, seleção e notas, Luciana Viégas- Rio de Janeiro: Grafia Editorial, 1992.

PEREIRA, L. M. Maria Luísa. In: PEREIRA, L. M. Ficção reunida. Curitiba: Ed. da UFPR, 2006.

PEREIRA, L. M. Em surdina. Rio de Janeiro: Ariel, 1933.

PEREIRA, L. M. Amanbecer. Rio de Janeiro: Livraria José Olympio, 1938. 
RODRIGUES, C. M. A Ordem - uma revista de intelectuais católicos 1934-1945. Belo Horizonte: Autêntica-Fapesp, 2005.

ROSENFELD, A. Literatura e personagem. In: CANDIDO, Antonio e et al. A personagem de ficção. São Paulo: Perspectiva, 2005.

SEGAL, N. Eco e Narciso. In: BRENNAN, T. (Org.). Para além do falo: uma crítica a Lacan do ponto de vista da mulher. Trad. Alice Xavier. Rio de Janeiro: Record/Rosa dos tempos, 1997. Coleção Gênero, V. 4. p. 225-249. WOOLF, V. Um teto todo seu. Trad. Vera Ribeiro. Rio de Janeiro: Nova Fronteira, 1985.

Recebido para publicação em 20 de novembro de 2012 . Aprovado em 12 de maio de 2013. 